\title{
On Software Engineering Courses with Industry Practice
}

\author{
Miaozhi Fang, Xun Lu* \\ School of Computer Science \& Technology, Soochow University, Suzhou, China \\ Email:1227402013@suda.edu.cn, luxun@suda.edu.cn
}

\begin{abstract}
We study the software engineering (training direction of embedded software) "how to industrial practice" course on our service outsourcing demonstration city and IT industry advantages, the use of Soochow University teaching conditions and resources, tube and Science in a series of teaching practice in the process of the process of organization, and introduces the concrete measures, and summarizes the experience, and gives further suggestions.
\end{abstract}

Keywords: Software Engineering, College Enterprise Cooperation, Corporate Training, Industry Practice, Outsourcing

\section{Introduction}

Suzhou University, Suzhou is the highest level of 211 regional comprehensive university, Computer Science and Technology, after 20 years of development, talent advantage is obvious, since 2004, in the Soviet Union business outsourcing software companies. The college has more than many companies and established practice base, some students take advantage of holidays or graduation gap initiative designed to short-term internship base, the two sides have achieved good results. Software Engineering into the seventh semester, according to the teaching plan, the need for "industrial practice" teaching the course, as the specialty of each there are more than many students in the session, but the course of the semester course schedule, how to organize students to carry out practical activities of enterprises facing a long time, large-scale, demand more problems.

Jiangsu Provincial Department of Education since years ago, launched a comprehensive international cooperation software talents training work, then the organization's some colleges cooperation with India NIIT training software professionals is an important part of the undergraduate level, and also in Jiangsu Provincial Department of Education to implement the provincial government. "an important measure of Training kinds of software talent, the task is to optimize the industrial structure of the provincial government an important strategic task, cooperation with India in the software engineering NIIT conducted in the teaching program, embedded in the company's India NIIT training system, the introduction of NIIT training materials, some of the courses taught by lecturers India NIIT, through four years of undergraduate education, speed up the training of software professionals to achieve priority Jiangsu software industry, accelerated cluster development. Soochow University School of Computer Science and Technology from years ago began to recruit the majors, in the seventh semester arrangement of "industrial practice" courses, students are required to participate fully in business internships, engaged in computer software-related internships. Training through internships for students to learn in a real environment and accept the workout, adapt to business rules and regulations, companies feel the atmosphere, improve the overall quality of students.

\section{Practical Skill Training}

IT personnel turnover rate of about 1/4 of enterprises, at the same time, as China vigorously promote the development of service outsourcing industry, software companies need to recruit new employees every year, hoping to recruit students that come ready to use, due to the increase in labor costs companies want to pre-employment training to complete the task by the school, more and more software engineering colleges, especially some independent software colleges, schools face the phenomenon of business needs and personnel training decoupling, the introduction of training links, 
to avoid the risk of employment and create conditions for student employment. Currently, the software engineering professional training are the following forms.

By the world's leading software company established college education or training centers, colleges and universities accept students to practice and training, and recommend work, such as IBM, Microsoft, NIIT. By the famous domestic software enterprises to participate in the teaching, the practical training introduced to teaching, such as the soft opened around the country, each year the juniors and seniors short-term internship training, a areas to meet the needs of the company's own personnel, but also talents for other companies.

The school's own training center organized by teachers with practical experience in the development or hire companies engaged in software development, a senior engineer to serve as lecturers, students strengthen comprehensive training to enhance skills. School established software development room, simulated business environment, from corporate engineer stationed in development room, the teacher in the school to assist management in the enterprise actual project development, and other enterprises to solve the problem of lack of space, students can within the school accepted practice and training.

Organize students to computer software related businesses internships allow students to experience working atmosphere and corporate culture, tested enterprise system, not only improve the overall quality, but also to get some economic benefits. Business process through internships, study Italian students, hiring meet the business needs of the students at the end of the internship.

\section{Industry Practice}

In response to the professional software engineering "industry practice" programs for large-scale student internships, college set up a training center, training center by the unified organization and management "industry practice" implementation of the curriculum. College firmly rely on the advantages of the IT industry in Suzhou, Suzhou region seize the opportunities of software talent gap is large, accumulated over the years through college and a lot of practice base in computer-related work alumni, multi-directional, multi-level conduct "industry practice" teaching curriculum.

In the course of the internship, the student needs of different levels, take please come in and go practice. For the job type. Such students volunteered to companies to practice, on the one hand to complete the course requirements, "industry practice", on the other hand you can get some reward. Suzhou as the outsourcing model cities and developed areas of the IT industry, the demand for software professionals is relatively large, some practice base of IT companies to recruit staff in line with the purpose of receiving student internships, students entering the business screening requirements, students will internship subsidy, which is an opportunity to "paid" internship. Meanwhile, the Suzhou Industrial Park in the park internship focused on college students have some subsidies, but also to make the park more aggressively for business internships. College of the organization of these companies recruit pre-publicity, training in schools, and through examination hire interns, paid internship batch of about $46 \%$ of the students. There are a number of student internships through independent contact to conduct internships, these students represent about $16 \%$.

Study section, type abroad. Suzhou University itself is "211" universities, broad choices after graduation may apply to a variety of directions to go abroad, PubMed and other development. To this end, the Institute organized a school training classes four directions, hire senior alumni to conduct training to students, such as students' daily commute saves time so that students have more time to prepare for examinations. These students account for about 29\%. School business training. For some of the weak hands, cannot meet the business requirements of the students, the college set up training center, opened a special site, set up a software development room, simulated business environment, organized in cooperation with the software to create Kunshan school for these students intensive training, equipped with four students who already headed security research, to pass, to help with a purpose. These students account for about $13 \%$. We carried out by multi-directional, multi-level practical training work, most of the students the ability to get exercise and training. 


\section{Problems Encountered}

In the "industrial practice" implementation of the courses, the college students in line without increasing the burden on the premise of meeting the needs of students at all levels, but there are also many problems.

The type of employment-oriented students are more scattered, some units only 1,2 classmate in practice, the larger the difference between the contents of jobs and internships, internships give guidance, management and assessment has brought no small difficulty. Some companies work intensity big, some internships for students directly involved in the development of the domestic well-known software services outsourcing company projects, withstood various exercises, students and business has been a win-win situation, but there are also some independent student internship job content is relatively simple work more relaxed, no real workout, reach the purpose of the course is teaching. Type for postgraduate students, some students began to have an enthusiastic prepare for graduate school, but later stop at the pro forma. There is a small part of the use of postgraduate internship work on behalf of circumvention, but college can not be forced to intervene. Some students even after school training courses, but because of the low intensity, not subjected to the test of actual companies, so in the course of employment, and the same period of the students participate in internships, compared encountered a shortage of some practical work experience, compressive strength weak obstacle.

Training of the students participating in the school business as companies can not engineer in the studio all day, plus part of the consciousness of the poor students can not focus on completing the internship courses, training effect is not ideal. Businesses, schools, individual students (between) the existence of demand differences . From "Industrial Training" course teaching plan view, as long as four months of internship, and after business school's assessment, you can obtain the corresponding credits, while some companies expect the internship for six months. Corporate campus recruitment conducted in November, and some outside internships for students unable to attend recruitment activities. Some students in internships demonstrated the ability and qualities won the appreciation of enterprises, ready to sign a tripartite employment agreement, but some student internships only gain experience in real time employment would otherwise choose. Therefore, enterprises have to pay a lot in the course of the internship, but did not really achieve results through internships complementary talents, thus affecting the organizational enthusiasm internship again.

\section{Solution}

For practice problems Academy in "industrial internship" organization and management of courses taken in a number of new processes and measures to achieve the goal of personnel training.

Amendments to the internship program. Did not really participate in internships for students exposes suited to the needs of enterprises work, work intensity suited to enterprise business rules suited. Practice has proved that only after the actual exercise of enterprises, in order to effectively improve the ability of all parties. "industrial internship" course "requires all students entering the internship, and arrange internships require relatively concentrated, so that management and assessment. Rely Suzhou Software outsourcing and advantages of the IT industry, contact a few large demand for talent enterprises to develop internships, one can strengthen practice guidance, on the other hand can unify require . level internship at 8-10 units started.

Prepare early. In the first semester of April 6, will carry out internships consultation and screening business, and good business practice to discuss related work, and ready to do the internship arrangements behind the students.

Good mobilization. From the beginning of May, to carry out from school leaders, senior director and teacher multi-level work, the demand for postgraduate internship and escape phenomenon, from the ideological unity of understanding, uniform requirements, strict management. Organize internship recruitment management. In June, the school performed in batches to arrange corporate lectures, organize business written test and interview. According to the results of business recruitment and student willingness to coordinate student internships, some students took part in the recruitment 
of more than one unit, and was hired, these students must sign to confirm internships. Signed internship agreement. According to the actual situation of each enterprise, colleges and companies signed internship agreement, clearly the rights and obligations of both parties and paid internships. As soon as possible into the practice. Take advantage of the summer months the time it was over the summer began, led by the instructor into the corporate practice, practice time on the one hand to achieve the business requirements of months, on the other hand can not delay the students to participate in 11 to 12 months campus recruitment activities. Offer internship site for information on all aspects of publicity internship, so transparent, open, and all aspects of practice for effective management. Training base rear. Students not selected enterprises, as well as failing to meet the assessment requirements were returned students, colleges take advantage of 211 colleges and universities, January September after school to reschedule training base training, training for a period of four months closed. On the one hand through intensive training, exercise capacity, on the other hand, let the students shortcomings, recognize their shortcomings, these students inspire enthusiasm for learning, striving for the industry to prepare enough. Through a series of work, students entered the proportion of actual internship increased to better at present, the ratio of students into internships reached better, practice problems arising in the course decreasing, "Industrial Internship "Implementation has entered a benign course track.

\section{Conclusion}

By three massive student practice administration and practice, and promote the work of personnel training colleges, colleges and deepen the cooperation between enterprises, so that the majority of businesses and students benefit, but also to ensure that the students of the high employment rate ; Internship also pointed out the direction for teaching other courses. Changing business needs, the aspirations of students are changing, the whole school is also training system reform, the contents of "industry practice" programs should be adjusted accordingly. Soochow University in this regard has already begun reforms, for different students' personal development plan, in high school stage, students can choose for the job applied orientation, students can choose to prepare for graduate school academic direction, past problems effectively carry out the work placement postgraduate student internship arrangements can be properly addressed.

Students do not want to stay in practice enterprises, is bound to bring companies to accept reduction internship enthusiasm, hard work eventually led to ongoing practice; after some companies hope to sign a tripartite agreement to be willing to start practical training; whether the work can be extended internships to 8th semester, many issues still need more schools, businesses, governments and other parties to explore cooperative solutions.

\section{Acknowledgements}

Miaozhi Fang, student ID Number: 1227402013, currently is an undergraduate student of Computer Science and Technology School of Soochow University. This work was directed by Xun Lu.

\section{References}

[1]. Gómez Gómez J, Huete J F, Hernandez Riaño V. Learning System Based on Contextual Awareness for Clinical Practice in Nursing Courses[C]. //Advanced Learning Technologies, IEEE International Conference on. IEEE, 2014:186 - 190.

[2]. Buchta J, Petrenko M, Poshyvanyk D, et al. Teaching Evolution of Open-Source Projects in Software Engineering Courses[C]. //Software Maintenance, 2006. ICSM '06. 22nd IEEE International Conference on. IEEE, 2006:136 - 144.

[3]. Mirian-Hosseinabadi S, Aghakasiri Z, Sadeghi A, et al. Emphasizing experiences in teaching software engineering courses[C]. //Education Technology and Computer (ICETC), 2010 2nd International Conference on. IEEE, 2010:V2-149 - V2-153. 
[4]. Brencich A, Gnecco M. Failure Case Studies in Structural Engineering Courses and Professional Practice[J]. Arabian Journal for Science and Engineering, 2012, 37(8):2113-2126.

[5]. Yamamoto M, Tomiyama H, Takada H, et al. NEXCESS: Nagoya university extension courses for embedded software specialists[J]. ACM SIGBED Review, 2005, (4).

[6]. Siqueira F L, Barbaran G M C, Becerra J L R. A Software Factory for Education in Software Engineering[J]. Software Engineering Education Conference, Proceedings, 2008.

[7]. Sun Y, Liu X. Educating students by "real-world" software engineering practice — Designing software engineering practice course[C]. //Computer Science and Education, International Conference on. IEEE, 2012:1356 - 1359.

[8]. Sun Y, Liu X. Educating students by "real-world" software engineering practice - Designing software engineering practice course[C]. //Computer Science and Education, International Conference on. IEEE, 2012:1356 - 1359.

[9]. Thompson J B, Edwards H M. Overview and Introduction to the Workshop on Best Practice in Software Engineering: The Role of Industry in Software Engineering[C]. //Software Engineering Education and Training Workshops, 2006. CSEETW '06. 19th Conference on. IEEE, 2006:16.

[10]. Di D, Xu L, Xin D. Research and practice on the cultivation mode of compound mainframe software talents with engineering practice background[C]. //Education Technology and Computer (ICETC), 2010 2nd International Conference on. IEEE, 2010:V4-104 - V4-108.

[11]. Dougherty J U, Parfitt M K. Framework for Teaching Engineering Capstone Design Courses with Emphasis on Application of Internet-Based Technologies.[J]. Journal of Architectural Engineering, 2009, (1):4-9.

[12].Jin C, Xiao X, Wei W. Strengthen practice ability and reform on a series of concrete structure courses for civil engineering specialty[J]. Journal of Architectural Education in Institutions of Higher Learning, 2010. 